\title{
FANCL Gene Mutation Negative
}

National Cancer Institute

\section{Source}

National Cancer Institute. FANCL Gene Mutation Negative. NCI Thesaurus. Code C159781.

A genetic finding indicating that FANCL gene mutations have not been detected in a sample. 